\title{
Characterization and Comparison of Different Cathode Materials for SC-SOFC: LSM, BSCF, SSC and LSCF
}

\author{
D. Rembelski ${ }^{1}$, JP. Viricelle ${ }^{1}$, L. Combemale ${ }^{2}$, M. Rieu ${ }^{1 *}$ \\ ${ }^{1}$ ENSMSE, Centre SPIN, département PRESSIC, 42023 Saint-Etienne, France, \\ ${ }^{2} \mathrm{ICB}, 21078$ Dijon, France, \\ [*]M.Rieu,rieu@emse.fr
}

\begin{abstract}
Four cathode materials for Single Chamber Solid Oxide Fuel Cell (SC-SOFC) $\left(\mathrm{La}_{0.8} \mathrm{Sr}_{0.2} \mathrm{MnO}_{3-\delta}\right.$ (LSM), $\mathrm{Ba}_{0.5} \mathrm{Sr}_{0.5} \mathrm{Co}_{0.8} \mathrm{Fe}_{0.2} \mathrm{O}_{3-\delta}$ (BSCF), $\mathrm{Sm}_{0.5} \mathrm{Sr}_{0.5} \mathrm{CoO}_{3-\delta}$ (SSC) and $\mathrm{La}_{0.6} \mathrm{Sr}_{0.4} \mathrm{Co}_{0.2} \mathrm{Fe}_{0.8} \mathrm{O}_{3-\delta}$ (LSCF)) were investigated regarding their chemical stability, their electrical conductivity, their catalytic activity and their polarization resistance under air and methane/air atmosphere. Electrolyte-supported fuel cells, with $\mathrm{Ce}_{0.9} \mathrm{Gd}_{0.1} \mathrm{O}_{2-\delta}(\mathrm{CGO})$ electrolyte and a Ni-CGO anode, were tested in several methane/air mixtures with each cathode materials between $625{ }^{\circ} \mathrm{C}$ and $725{ }^{\circ} \mathrm{C}$. These single cells were not optimized but only designed to compare the four studied cathodes. The decrease of methane-tooxygen ratio from 2 to 0.67 strongly increased the performance of fuel cells for all cathode materials but the effect of temperature was not always significant. Cells with SSC, BSCF and LSCF have shown a maximum power density about $20 \mathrm{~mW} \mathrm{~cm}^{-2}$ while the cell with LSM has given only $5 \mathrm{~mW} \mathrm{~cm} \mathrm{~cm}^{-2}$.
\end{abstract}

Keywords: BSCF, Cathode materials, LSCF, LSM, Single Chamber, Solid Oxide Fuel cell, SSC.

\section{Introduction}

Single Chamber Solid Oxide Fuel Cells (SC-SOFC) show a growing interest and are the concern of more and more papers [1-2]. In such device, anode and cathode are exposed to a gas mixture of fuel (hydrocarbon) and oxidant (air) so that no more sealing with electrolyte is necessary. Their operating principle is based on the different catalytic activities of anode and cathode. Ideally, the anode has to be active for the partial oxidation of fuel (reaction I) and then for the electrochemical oxidation of hydrogen (reaction II) while the cathode should present only a strong electro-catalytic activity for oxygen electrochemical reduction (reaction III). The methane, which is one of the most common fuels used in SC-SOFC, was chosen for this work.

The partial oxidation of fuel (reaction I, stoichiometric ratio $\mathrm{CH}_{4} / \mathrm{O}_{2}=2$ ) must predominate because the full oxidation (reaction IV, stoichiometric ratio $\mathrm{CH}_{4} / \mathrm{O}_{2}=0.5$ ) doesn't produce hydrogen. A compromise $\mathrm{CH}_{4} / \mathrm{O}_{2}$ ratio has to be defined: indeed, to prevent the carbon formation on the anode, a rich fuel mixture must be avoided, and to prevent the oxidation of the nickel, a too rich oxygen mixture is not suitable. It has been showed that $\mathrm{CH}_{4} / \mathrm{O}_{2}$ ratio must be in the range $0.5-2[3]$.

$$
\begin{array}{cl}
\text { Anode: } & \mathrm{CH}_{4}+1 / 2 \mathrm{O}_{2} \rightarrow 2 \mathrm{H}_{2}+\mathrm{CO} \\
\mathrm{H}_{2}+\mathrm{O}^{2-} \rightarrow \mathrm{H}_{2} \mathrm{O}+2 \mathrm{e}^{-} & \text {(I) } \\
\text { Cathode: } & \mathrm{O}_{2}+4 \mathrm{e}^{-} \rightarrow 2 \mathrm{O}^{2-}
\end{array}
$$

Full oxidation of methane: $\mathrm{CH}_{4}+2 \mathrm{O}_{2} \rightarrow 2 \mathrm{H}_{2} \mathrm{O}+\mathrm{CO}_{2}$

In the first studies on SC-SOFC, yttria-stabilised zirconia (YSZ) was used as electrolyte like in conventional SOFC, but in order to reduce the working temperature, the trend is to use other materials like $\mathrm{La}_{0.8} \mathrm{Sr}_{0.2} \mathrm{Ga}_{0.8} \mathrm{Mg}_{0.2} \mathrm{O}_{3}$ (LSGM) and ceria doped with gadolinium (CGO) or samarium (CSO). Below $\sim 650{ }^{\circ} \mathrm{C}$, doped ceria has a better ionic conductivity than LSGM [4] and this improves the power density [5]. The difference between CGO and CSO is not relevant [6], but some studies show better ionic conductivity for CGO [7]. The ionic conductivity depend on doping percentage, the best $\mathrm{Ce}_{1-\mathrm{x}} \mathrm{Gd}_{\mathrm{x}} \mathrm{O}_{2-0.5 \mathrm{x}}$ is $\mathrm{Ce}_{0.9} \mathrm{Gd}_{0.1} \mathrm{O}_{1.95}$ with a conductivity of $0.025 \mathrm{~S} \mathrm{~cm}^{-1}$ at $600{ }^{\circ} \mathrm{C}$ according to Steele [7]. To enhance the cells performance, the electrolyte must have a small thickness [8] and a smooth surface [9].

The anode material commonly used is a cermet with nickel and the electrolyte material. Many studies have been done on the anode to increase the performance of the cells particularly on the Ni/electrolyte ratio [8], on the thickness of the anode [10] or the addition of noble metals as catalysers [11]. Furthermore, some researches were performed on the operation conditions to avoid the re-oxidation of nickel [12].

Many cathode materials were used by different research groups; $\mathrm{La}_{0.8} \mathrm{Sr}_{0.2} \mathrm{MnO}_{3-\delta}$ (LSM) and $\mathrm{Sm}_{0.5} \mathrm{Sr}_{0.5} \mathrm{CoO}_{3-\delta}\left(\mathrm{SSC}_{\text {) }}\right.$ were the most used materials in the first SC-SOFC development [8-13-14], and new materials were studied like $\mathrm{Ba}_{0.5} \mathrm{Sr}_{0.5} \mathrm{Co}_{0.8} \mathrm{Fe}_{0.2} \mathrm{O}_{3-\delta}$ (BSCF) [15] and $\mathrm{La}_{0.6} \mathrm{Sr}_{0.4} \mathrm{Co}_{0.2} \mathrm{Fe}_{0.8} \mathrm{O}_{3-\delta}$ (LSCF) [16]. The thermo-mechanical compatibility between electrolyte and cathode is improved by mixing the cathode material with the electrolyte material [17] and a composite cathode has also a better ionic conductivity; the cathode overpotential is thus significantly reduced [18-19].

Only few papers made a comparison between different cathodes. The power density of YSZ electrolyte-supported fuel cells with SSC, LSM and LSCF as cathode was compared in air/propane atmosphere (90/10) at $600{ }^{\circ} \mathrm{C}$ by Jasinski 


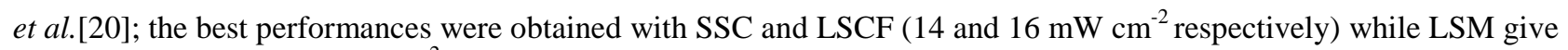
lower power density $\left(4 \mathrm{~mW} \mathrm{~cm}^{-2}\right)$.

In the present paper, the main objective is to compare cathode materials in single chamber fuel cell conditions. The properties of four cathode materials (LSM, LSCF, BSCF and SSC) are compared regarding their chemical stability, electrical conductivity, catalytic activity towards methane and polarization resistance. Complete cells were prepared with these cathodes to compare the obtained power density. Electrolyte-supported configuration was chosen for this study because of a more convenient fabrication and because the main objective is not the fuel cell optimization. The influences of temperature and $\mathrm{CH}_{4} / \mathrm{O}_{2}$ ratio were also investigated. The whole results are discussed to select the best cathode material for this application.

\section{Experimental}

\subsection{Materials, Cells Preparation}

Commercials powders were used in this work for the cathode, the anode and the electrolyte. There specifications are listed in Table 1.

Electrolytes pellets were fabricated by pressing $2 \mathrm{~g}$ of $100 \mu \mathrm{m}$ sieved CGO powder at $100 \mathrm{MPa}$. They were then annealed with a protocol previously established [21]: $1200{ }^{\circ} \mathrm{C}$ during 6 hours and $1350{ }^{\circ} \mathrm{C}$ during 4 hours with temperature rise of $10{ }^{\circ} \mathrm{C} \mathrm{min}^{-1}$. Electrolytes were then polished by successive grinding paper of 120,300 and 600 . Electrolyte pellets have a diameter of $19 \mathrm{~mm}$, a thickness of $1 \mathrm{~mm}$ and a densification about $94 \%$.

Electrodes were deposited by screen-printing technique on the whole surface of the electrolyte (electrodes size of $2.8 \mathrm{~cm}^{2}$ ). All inks were composed of ceramic powders, commercial binder (ESL V400, $0.5 \mathrm{~g}$ per gram of powder) and solvent (ESL T404, 8 drops per gram of powder). The obtained paste was homogenized and desagglomerated by a rolling-mill.

For cathode preparation, CGO was added to LSM, BSCF, LSCF and SSC with a cathode/electrolyte weight ratio of 70/30, a ratio which has shown good performances [15]. In this work, a layer called SSC/CGO is constituted of SSC (70 $\mathrm{wt} \%)$ and CGO $(30 \mathrm{wt} \%)$. For BSCF/CGO preparation, because of the important size of BSCF aggregates $(\sim 10 \mu \mathrm{m})$ compared to other cathode powders $(\sim 1-3 \mu \mathrm{m})$, BSCF powder was previously grinded in a ball mill during 8 hours in ethanol. The grinded BSCF particles were measured by granulometry and have an average size of $4 \mu \mathrm{m}$, close to the other cathode powders particle size.

A composite anode was prepared by mixing $60 \mathrm{wt} \%$ of $\mathrm{NiO}$ and $40 \mathrm{wt} \%$ of CGO.

For electrical conductivity measurement, two cathode layers were deposited by screen-printing on previous CGO substrate and annealed during 2 hours at $950{ }^{\circ} \mathrm{C}$ for SSC/CGO, $1100{ }^{\circ} \mathrm{C}$ for BSCF/CGO and LSCF/CGO, and $1200{ }^{\circ} \mathrm{C}$ for LSM/CGO, following a previous protocol [21]. The thickness of cathode layers is about $20 \mu \mathrm{m}$.

The polarization resistance measurement was performed on symmetrical cathodes (2 layers) coated on both side of the electrolyte pellet. A gold mesh was finally deposited on each cathode by screen-printing, using a commercial gold ink (ESL 8880-H), and annealing at $900{ }^{\circ} \mathrm{C}$ during 2 hours.

For electrolyte-supported fuel cell fabrication, 4 layers of anode $(\sim 50 \mu \mathrm{m})$ were first deposited by screen-printing on CGO pellet and annealed at $1200{ }^{\circ} \mathrm{C}$ during $2 \mathrm{~h} ; 2$ layers of cathode $(\sim 20 \mu \mathrm{m})$ were then deposited by screen-printing on the other side of CGO pellet and annealed following the previous protocol. The same gold mesh as for the polarization resistance cells was coated on cathode side.

\subsection{Characterization Tests}

X-ray diffraction (XRD) analyses were performed with a Siemens D5000 diffractometer using $\mathrm{Cu} \mathrm{K}_{\alpha}$ radiation at 40 $\mathrm{kV}$ and $40 \mathrm{~mA}$. Microstructures of cathode layers were characterized by a scanning electron microscope (SEM) Jeol JSM 6400.

For all characterization tests using methane, the concentration of oxygen is set at $10 \%$ of the total volume to avoid the flammability area of the mixture.

Concerning the study of cathode stability, 200mg of each powder was placed into a furnace at $600{ }^{\circ} \mathrm{C}$ during 5 hours. The atmosphere was composed with a ratio $\mathrm{CH}_{4} / \mathrm{O}_{2}=1.5$ balanced with nitrogen with a total gas flow of $24 \mathrm{~L} \mathrm{~h}^{-1}$.

As for electrical measurement, gold wires without catalytic activity were used. Electrical conductivity was performed by the 4-probes Van der Pauw method on cathodes layers in a quartz tubular furnace $(\varnothing=30 \mathrm{~mm})$, using a Keithley 6430 digital source meter. The experiment was performed in air first and then under a gas flow mixture with a ratio $\mathrm{CH}_{4} / \mathrm{O}_{2}=1$ balanced with nitrogen at $20 \mathrm{~L} \mathrm{~h}^{-1}$ from $200{ }^{\circ} \mathrm{C}$ to $550{ }^{\circ} \mathrm{C}$.

For the study of cathode catalytic activity, a powder bed was maintained in the middle of a vertical furnace by quartz wool. The inlet gas $\left(\mathrm{CH}_{4} / \mathrm{O}_{2}=1\right.$ and 2 balanced with argon) flowed through this bed at $15 \mathrm{~L} \mathrm{~h}{ }^{-1}$ from $400^{\circ} \mathrm{C}$ to $700^{\circ} \mathrm{C}$, and the outlet gases $\left(\mathrm{H}_{2}, \mathrm{CH}_{4}, \mathrm{CO}_{2}, \mathrm{CO}, \mathrm{O}_{2}\right)$ were analyzed with a micro-chromatograph (SRA Instruments ${ }^{\mathrm{TM}}$ ).

The impedance spectroscopy were performed on symmetrical cells with Solartron 1286 combined with a Solartron 1255. The frequency range is from $100 \mathrm{kHz}$ to $10 \mathrm{mHz}$ with an amplitude of $10 \mathrm{mV}$. Zplot 2.6 and ZView 3.2c softwares were used to collect and to analyze the data. The cells were placed into a quartz tubular furnace from $600{ }^{\circ} \mathrm{C}$ to $700{ }^{\circ} \mathrm{C}$ in air then $\mathrm{CH}_{4} / \mathrm{O}_{2}=1$ and finally $\mathrm{CH}_{4} / \mathrm{O}_{2}=2$ with a total gas flow of $20 \mathrm{~L} \mathrm{~h}^{-1}$.

The current and the voltage data of complete SC-SOFC were collected with a Keithley 2400 from $725{ }^{\circ} \mathrm{C}$ to $625{ }^{\circ} \mathrm{C}$ for $\mathrm{CH}_{4} / \mathrm{O}_{2}=0.67,1,1.5$ and 2 with a total gas flow of $30 \mathrm{~L} \mathrm{~h}^{-1}$. Each ratio was investigated at a determinate temperature 
from the most reducing mixture $\left(\mathrm{CH}_{4} / \mathrm{O}_{2}=2\right)$ to the less reducing mixture $\left(\mathrm{CH}_{4} / \mathrm{O}_{2}=0.67\right)$. During the decreasing of temperature between each temperature stage, a ratio of $\mathrm{CH}_{4} / \mathrm{O}_{2}=2$ was injected to avoid a possible anode oxidation.

In all those characterizations, the given temperature is the "sample temperature" measured thanks to a thermocouple located near the sample.

\section{Results}

\subsection{Stability of cathode powders}

In order to evaluate the degradation of powder, XRD patterns were compared between initial powders and powders after 5 hours at $600{ }^{\circ} \mathrm{C}$ with $\mathrm{CH}_{4} / \mathrm{O}_{2}=1.5$. The results are shown in Figure 1. LSM and LSCF were not damaged by this test contrary to BSCF and SSC. Indeed, there is the formation of several carbonates for BSCF and SSC. The initial powder of SSC has some unidentified impurity which can also increase the degradation. The formation of carbonates has already been observed for BSCF in the presence of $\mathrm{CO}_{2}$ [22] and Song et al. have observed the degradation of SSC into $\mathrm{Sm}_{2} \mathrm{O}_{3}$ in a strong reducing atmosphere [23]. This test was performed for only 5 hours but it shows that BSCF and SSC are less stable than LSM and LSCF.

\subsection{Electrical Conductivity of Cathode Layers}

The cathode must have a good ionic and electrical conductivity, this last parameter were measured on each composite cathode by the Van der Pauw method. The results under air and $\mathrm{CH}_{4} / \mathrm{O}_{2}=1$ are shown in Figure 2 . The measured electrical conductivities $(\sigma)$ for all the cathode layers are about 10 times lower than the values of the literature (Table 1) at $600{ }^{\circ} \mathrm{C}$. It must be noted that reported values in Table 2 were measured with dense pellets cathodes without CGO contrary to the present data that were performed on composite cathode layer prepared by screen-printing, which bring some porosity. Nonetheless, the experimental conductivities show the same trend as in literature: SSC has the best conductivity, then it is LSCF, LSM and BSCF. There is no significant difference between air and $\mathrm{CH}_{4} / \mathrm{O}_{2}=1$ atmosphere and XRD analyses didn't show any degradation of all cathode materials after the measurement. Contrary to the previous stability test $\left(\mathrm{CH}_{4} / \mathrm{O}_{2}=1.5\right)$, SSC and BSCF were not degraded probably because of less reducing condition $\left(\mathrm{CH}_{4} / \mathrm{O}_{2}=1\right)$ and the short duration of the test on screen-printed layer.

It has been observed that the conductivity of SSC/CGO decreases when temperature is increased contrary to the other materials; this behavior of SSC has already been noticed in literature [24].

\subsection{Catalytic Activity of Cathode Powders}

In SC-SOFC, the cathode must be active toward the reduction of oxygen (reaction III) and mustn't be active toward fuel oxidation (reactions I and IV). Hence, measurements of catalytic activity were performed in several conditions to find the cathode materials which have the lowest activity towards methane conversion.

Catalytic activity (CA) is usually calculated as production or consumption rate of gas per powder surface area (mol $\mathrm{h}^{-1} \mathrm{~m}^{-2}$ ). Thus, the comparison is reliable even if the morphologies of powder are different. Whatever the cathode used in this experiment, only the carbon dioxide was detected as a reaction gas, so only the total oxidation of methane happened. Thus, the catalytic activity (CA) was calculated toward to the production rate of $\mathrm{CO}_{2}$ for each cathode material (Eq. 1).

$$
\mathrm{CA}=\frac{\mathrm{P}_{\mathrm{CO}_{2}} \times \mathrm{GF}_{\mathrm{tot}}}{\mathrm{R} \times \mathrm{T}} \times \frac{1}{\mathrm{~S} \times \mathrm{m}}(1)
$$

With $\mathrm{P}_{\mathrm{CO} 2}$ the partial pressure of $\mathrm{CO}_{2}(\mathrm{~Pa})$, the $\mathrm{GF}_{\text {tot }}$ the total gas flow $\left(\mathrm{m}^{3} \mathrm{~h}^{-1}\right)$, R the gas constant $\left(8.31 \mathrm{~J} \mathrm{~K}^{-1} \mathrm{~mol}^{-1}\right)$, $\mathrm{T}$ the temperature $(\mathrm{K}), \mathrm{S}$ the specific surface area of powder $\left(\mathrm{m}^{2} \mathrm{~g}^{-1}\right)$ and $\mathrm{m}$ the mass of powder $(\mathrm{g})$.

Catalytic activity results are shown in Figure 3. For all the cathodes, the catalytic activity increase with temperature and the $\mathrm{CH}_{4} / \mathrm{O}_{2}$ ratio. For fuel cell test, a too low functioning temperature may oxidize the nickel [12], so the range 600$700{ }^{\circ} \mathrm{C}$ is more appropriate working with methane. In this range, LSCF has the higher catalytic activity, then it is LSM; BSCF and SSC materials have almost the same activity which is the lowest.

\subsection{Polarization Resistance}

The polarization resistance measurement was performed on one symmetrical cathode cell of each material under air atmosphere first, then $\mathrm{CH}_{4} / \mathrm{O}_{2}=1$ and finally $\mathrm{CH}_{4} / \mathrm{O}_{2}=2$, from $600{ }^{\circ} \mathrm{C}$ to $700^{\circ} \mathrm{C}$. Figure 4 shows the results of LSCF/CGO cell under air atmosphere. These results are representative of the trend of all cathodes i.e. the cathode resistance (low frequencies) and the electrolyte resistance (high frequencies) decrease when the temperature increase.

Comparison of polarization resistances $(\mathrm{Rp})$ between different atmospheres for each cathode is shown in Figure 5. The effect of the mixture ratio is not significant for LSM/CGO and LSCF/CGO, but for BSCF/CGO and SSC/CGO, the polarization resistance increase when $\mathrm{CH}_{4} / \mathrm{O}_{2}$ ratio increases. This can be due to the degradation of these cathodes under $\mathrm{CH}_{4} / \mathrm{O}_{2}$ mixtures ( $c f$. §3.1) [28]. But even after the degradation, SSC and BSCF have a polarization resistance lower than LSCF and LSM. The results under air at $650{ }^{\circ} \mathrm{C}$ are compared in Table 3. LSM/CGO cathode has a huge 
polarization resistance compared to the others cathodes, then it is LSCF/CGO, after it is BSCF/CGO and the cathode $\mathrm{SSC} / \mathrm{CGO}$ has the lowest polarization resistance.

Microstructure of layers can influence the polarization resistance so cross-sections of cathode layers were investigated with a Scanning Electron Microscope (Figure 6). From these micrographs, all the cathodes have almost the same thickness of $20 \mu \mathrm{m}$. It is noticed that microstructures of LSM/CGO, LSCF/CGO and SSC/CGO are similar with a small size of grains and pores $(0.5-2 \mu \mathrm{m})$ but their polarization resistances are very different. Furthermore, SSC/CGO and $\mathrm{BSCF} / \mathrm{CGO}$ have different microstructures but they both have low polarization resistances. Therefore, the microstructure of layer does not seem to be the predominant parameter for polarization resistance of cathodes. From these results, LSM/CGO cathode does not seem to be a suitable cathode for fuel cell application.

\subsection{Fuel Cell Investigation}

Polarization curves were measured for each cell, ratio and temperature. The trend of all cell are similar, the cell $\mathrm{Ni} / \mathrm{CGO} / / \mathrm{CGO} / / \mathrm{LSCF} / \mathrm{CGO}$ was chosen to illustrate the results. The influence of temperature for $\mathrm{CH}_{4} / \mathrm{O}_{2}=2$ and 0.67 is presented in Figure 7. For a rich fuel mixture $\left(\mathrm{CH}_{4} / \mathrm{O}_{2}=2\right)$, the decrease of temperature strongly increases the OCV (open circuit voltage), while for $\mathrm{CH}_{4} / \mathrm{O}_{2}=0.67$, the decrease of temperature slightly increases the OCV. The influence of $\mathrm{CH}_{4} / \mathrm{O}_{2}$ ratio at $675^{\circ} \mathrm{C}$ is shown in Figure 8 . The maximum power density increases when the $\mathrm{CH}_{4} / \mathrm{O}_{2}$ ratio decreases. This evolution follows the same variation as the OCV which increases when the $\mathrm{CH}_{4} / \mathrm{O}_{2}$ ratio decreases. Indeed, the internal resistance of the cell (slope $\mathrm{U}=\mathrm{f}(\mathrm{I})$ ) does not change for a constant temperature. These OCV variations can be correlated with the results on cathode catalytic activity. Indeed, the decreasing of the temperature and $\mathrm{CH}_{4} / \mathrm{O}_{2}$ ratio both limit the cathode activity toward methane conversion; the OCV, which results from the difference of catalytic activity between anode and cathode, is then increased. This trend for OCV has been observed for all cathode materials. However, the cell with the highest OCV doesn't necessarily give the best performance because the decrease of temperature increases the polarization resistance of electrodes and reduces the ionic conductivity of electrolyte.

In order to give a clear overview of the cross influence of temperature and $\mathrm{CH}_{4} / \mathrm{O}_{2}$ ratio on cell performances, 3D representation of maximum power density is reported in Figure 9 for each cathode materials. The decrease of the ratio from 2 to 0.67 sharply increases the performances for each cathode at all temperature. Temperature influence on power density is somewhat less clear. For rich methane mixture, power densities are generally improved when temperature decreases. But, for $\mathrm{CH}_{4} / \mathrm{O}_{2}=0.67$, the effect of temperature is not significant, except for cell with BSCF/CGO which gives the best performances only for $\mathrm{CH}_{4} / \mathrm{O}_{2}=0.67$ at $725^{\circ} \mathrm{C}$. Concerning cathode material influence, it appears that the cell with LSM/CGO cathode has the lowest power density $\left(5 \mathrm{~mW} \mathrm{~cm}^{-2}\right)$; maximum power density of the cells with other cathodes are almost equivalent (BSCF/CGO: $22 \mathrm{~mW} \mathrm{~cm}^{-2}$, SSC/CGO: $23 \mathrm{~mW} \mathrm{~cm}^{-2}$, LSCF/CGO: $21 \mathrm{~mW} \mathrm{~cm}^{-2}$ ).

An important effect of methane-to-oxygen ratio is observed: the power density increases when $\mathrm{CH}_{4} / \mathrm{O}_{2}$ ratio decreases. This phenomenon is attributed to the OCV which increase when $\mathrm{CH}_{4} / \mathrm{O}_{2}$ ratio decrease and it is correlated with the decrease of the catalytic activity of cathode when $\mathrm{CH}_{4} / \mathrm{O}_{2}$ ratio decrease. However, this trend is not clearly established in the literature. Akhtar et al. have shown a similar trend: the increase of OCV coming with an increase of performance from $\mathrm{CH}_{4} / \mathrm{O}_{2}=4.76$ to $\mathrm{CH}_{4} / \mathrm{O}_{2}=1$ [29]. Hibino et al. have observed a decrease of OCV from $\mathrm{CH}_{4} / \mathrm{O}_{2}=2$ to $\mathrm{CH}_{4} / \mathrm{O}_{2}=1$ but the performances are better for the lowest $\mathrm{CH}_{4} / \mathrm{O}_{2}$ ratio [11]. It can be noticed that in these papers, where a diminution of the $\mathrm{CH}_{4} / \mathrm{O}_{2}$ ratio improves the power density, the lower $\mathrm{CH}_{4} / \mathrm{O}_{2}$ ratio investigated is equal to 1 . This minimum ratio can be explained by a possible oxidation of the anode for a too high oxygen concentration. In this work, the decrease of $\mathrm{CH}_{4} / \mathrm{O}_{2}$ ratio until 0.67 is enough to keep the anode in a reduced form maybe because the initial oxygen concentration is set at $10 \%$ of the total volume. Contrary to our results, Napporn et al. [30] and Zhu et al. [31] have observed an increase of OCV when methane-to-oxygen ratio increases at a temperature above $700^{\circ} \mathrm{C}$ and they obtain the best performances for a $\mathrm{CH}_{4} / \mathrm{O}_{2}$ ratio between 1.5 and 2. Those differences also point out the strong influence of the whole geometry of the device including the SC-SOFC itself (materials, electrode and electrolyte thicknesses and porosity), the total gas flow and the test bench geometry.

\section{Discussions}

In this work, the stability results show the degradation of BSCF and SSC under single chamber conditions. But in other studies, high power densities were obtained with these cathodes: $644 \mathrm{~mW} \mathrm{~cm}^{-2}$ with a SSC based cathode [11] and $760 \mathrm{~mW} \mathrm{~cm}^{-2}$ with a BSCF based cathode [15]. However, the evolution of these performances during a long duration has not been investigated.

The electrical conductivity of porous cathode layer is rarely mentioned in literature and a too low conductivity could reduce the performances of cells. In polarization and fuel cell test, this parameter does not seem to be predominant because of the addition of a gold mesh on the cathode which increases the current collection. Indeed, SSC/CGO and $\mathrm{BSCF} / \mathrm{CGO}$ have similar results concerning both polarization resistance and maximum power density for fuel cell test in spite of a different value of conductivity.

Concerning catalytic activity, only few authors compared this property on cathode. Shao et al. compared LSCF, SSC and BSCF under a propane/air mixture [32] and show a lower catalytic activity for BSCF and SSC than for LSCF. Gaudillère et al. have shown a high catalytic activity of LSM compared to BSCF under methane/air mixture [33]. Their conclusions concur with the results presented here with a lower catalytic activity for SSC and BSCF than for LSM and LSCF. 
As regards of polarization resistance, various authors mention that LSM cathodes have a higher polarization resistance than BSCF [33] and LSCF [34]. In this work, the results on polarization resistance of cathode follow this trend and it can be added that the LSCF based cathode shows a polarization resistance which is at least 5 times bigger than BSCF and SSC based cathodes.

For the complete cells results, the maximum power density of the cell with LSM/CGO cathode is 4 times lower than the cell with other cathodes.

By analyzing the catalytic activity and the conductivity, LSM is not the worst material, but it has a huge polarization resistance at least 100 times bigger than the other cathodes. This last parameter is important for optimization of fuel cell. As a consequence of all these results, LSM is not a suitable material to improve the performances of SC-SOFC. It concurs with the conclusions of Jasinski et al. [20].

For the other cathode materials, in spite of different properties, they give a similar power density on fuel cells. It seems that BSCF/CGO, SSC/CGO and LSCF/CGO cathodes are not the limiting elements of the cells which can be the anode or the electrolyte. In our case, the electrolyte with a thickness of $1 \mathrm{~mm}$ seems to impose the overall polarization resistance of the cells. Anode-supported cell with a thin electrolyte could decrease the contribution of the electrolyte in the whole cell, so that the contribution of the cathode could be more significant. This could allow a better understanding of the correlation between the electrical conductivity, the catalytic activity, the polarization resistance and the performance of the cell. Such devices are under investigation at this time.

The present results on complete cells are not sufficient to clearly distinguish the best cathode between BSCF/CGO, SSC/CGO and LSCF/CGO. The cell with LSCF based cathode shows similar results compared to cells with BSCF and $\mathrm{SSC}$, in spite of a higher catalytic activity and polarization resistance than these cathodes. This point is also verified in literature with a maximum power density of $660 \mathrm{~mW} \mathrm{~cm}^{-2}$ [16] for a cell with LSCF based cathode. So LSCF material seems to be the best cathode material because it is not degraded under single chamber conditions contrary to BSCF and $\mathrm{SSC}$, and this point is crucial for a long life application.

\section{Conclusions}

The comparison between four cathode materials (LSM, BSCF, SSC and LSCF), dedicated to SC-SOFC device, was done regarding their stability under methane/air mixture, their electrical conductivity, their catalytic activity and their polarization resistance. Electrolyte-supported fuel cells have been prepared with each cathode to measure the power density versus $\mathrm{CH}_{4} / \mathrm{O}_{2}$ ratio and temperature.

The comparison of these properties indicates that LSM is not suitable for SC-SOFC because of a too high polarization resistance.

Concerning the behavior of all fuel cells, an increase of power densities was observed when $\mathrm{CH}_{4} / \mathrm{O}_{2}$ ratio decreased. This is mainly due to an increase of the OCV. The comparison of cathode on complete cell does not show a significant difference on the maximum power density for cells with BSCF, SSC and LSCF based cathodes. This is due to the important polarization resistance of the electrolyte.

Regarding SSC and BSCF materials, they have a low catalytic activity toward methane oxidation and a low polarization resistance, but they are degraded under single chamber conditions. For an application with a long durability, these cathodes should be avoided. Although some properties of LSCF material are lower than those of BSCF and SSC (catalytic activity and polarization resistance), it has the advantage to be stable under single chamber conditions. Therefore, LSCF seems to be the most promising cathode material.

\section{Acknowledgments}

The authors wish to thanks ADEME for financial support of this study in the frame of "MONOPAC500" project and all the partners for fruitful collaboration, IRCELYON, Saint Gobain, LEPMI and ICB.

\section{References}

[1] M. Yano, A. Tomita, M. Sano, T. Hibino, Solid State Ionics 2007, 177, 3351.

[2] M. Kuhn,T. Napporn, Energies 2003, 3, 57.

[3] B. Buergler, A. Grundy, L. Gauckler, J. Electrochemical Society 2006, 153, 1378.

[4] SC. Singhal, K. Kendall, High Temperature Solid Oxide Fuel Cells: Fundamentals, Design and Applications, ELSEVIER, 2003, pp. 84

[5] T. Hibino, A. Hashimoto, T. Inoue, J. Tokuno, S. Yoshida, M. Sano, Science 2000, 288, 2031.

[6] S. Zha, C. Xia, et G. Meng, J. Power Sources 2003, 115, 44.

[7] B. C. H. Steele, Solid State Ionics 2000, 129, 95.

[8] T. Hibino, A. Hashimoto, T. Inoue, J. Tokuno, S. Yoshida, M. Sano, J. Electrochemical Society 2000, $147,2888$.

[9] T. Hibino, A. Hashimoto, M. Suzuki, M. Yano, S. Yoshida, M. Sano, J. Electrochemical Society 2002, $149,195$.

[10] B. Buergler, Y. Santschi, M. Felberbaum, L. Gauckler, Adv Solid Oxide Fuel Cells II 2007, $27,37$.

[11] T. Hibino, A. Hashimoto, M. Yano, M. Suzuki, S. Yoshida, M. Sano, J. Electrochemical Society 2002, $149,133$.

[12] G. Gadacz, S. Udroiu, J. Viricelle, C. Pijolat, M. Pijolat, J. Electrochemical Society 2010, 157, 1180.

[13] T. Hibino, S. Wang, S. Kakimoto, M. Sano, Solid State Ionics 2000, 127, 89. 
[14] T. Hibino, S. Wang, S. Kakimoto, M. Sano, Electrochem. Solid-State Lett. 1999, 2, 317.

[15] Z. Shao, J. Mederos, W. C. Chueh, S. Haile, J. Power Sources 2006, 162, 589.

[16] T. Suzuki, P. Jasinski, V. Petrovsky, H. Anderson, F. Dogan, J. Electrochemical Society 2005, $152,527$.

[17] M. Kuhn, T. Napporn, M. Meunier, D. Therriault, Solid State Ionics 2010, 181, 332.

[18] S. Jiang, W. Wang, Solid State Ionics 2005, 176, 1351.

[19] S. Lee, P. Muralidharan, S. Jo, D. Kim, Electrochem. Commun. 2010, 12, 808.

[20] P. Jasinski, T. Suzuki, X. Zhou, F. Dogan, H. Anderson, Ceram. Eng. Sci. Proc. 2003, 24, 293.

[21] J. Viricelle, S. Udroiu, G. Gadacz, M. Pijolat, C. Pijolat, Fuel Cells 2010, 10, 683.

[22] W. Zhou, R. Ran, Z. Shao, J. Power Sources 2009, 192, 231.

[23] H. Song, J. Min, J. Kim, J. Moon, J. Power Sources 2009, 191, 269.

[24] H. Lv, Y. Wu, B. Huang, B. Zhao, K. Hu, Solid State Ionics 2006, 177, 901.

[25] J. Mizusaki et al., Solid State Ionics 2000, 132, 167.

[26] E. Tsipis et V. Kharton, J. Solid State Electrochem. 2008, 12, 1367.

[27] S. Li, Z. Lu, X. Huang, B. Wei, et W. Su, J. Phys. Chem. Solids 2007, 68, 1707.

[28] A. Yan, M. Cheng, Y. Dong, W. Yang, V. Maragou, S. Song, P. Tsiakaras, Appl. Catal. B 2006, 66, 64.

[29] N. Akhtar, S.P. Decent, D. Loghin, K. Kendall, J. Power Sources 2009, 193, 39.

[30] X. Jacques-Bédard, T. Napporn, R. Roberge, M. Meunier, J. Power Sources 2006, 153, 108.

[31] X. Zhu, Z. Lü, B. Wei, Y. Zhang, X. Huang, W. Su, Int. J. Hydrogen Energy 2010, 35, 6897.

[32] Z. Shao, S.M. Haile, Nature, 2004, 431, 170.

[33] C. Gaudillère, L. Olivier, P. Vernoux, C. Zhang, Z. Shao, D. Farrusseng. J. Power Sources 2010, $195,4758$.

[34] P. Leone, M. Santarelli, P. Asinari, M. Cali, R. Borchiellini, J. Power Sources, 2008, 177, 111.

Table 1: Powders specification

\begin{tabular}{|c|c|c|c|c|c|}
\hline Name & Composition & Part of the cell & Supplier & $\mathrm{d}_{50}(\mu \mathrm{m})$ & $\mathrm{S}_{\mathrm{BET}}\left(\mathrm{m}^{2} \mathrm{~g}^{-1}\right)$ \\
\hline $\mathrm{LSM}$ & $\mathrm{La}_{0.8} \mathrm{Sr}_{0.2} \mathrm{MnO}_{3-\delta}$ & Cathode & St Gobain & 0.7 & 7.85 \\
\hline $\mathrm{BSCF}$ & $\mathrm{Ba}_{0.5} \mathrm{Sr}_{0.5} \mathrm{Co}_{0.8} \mathrm{Fe}_{0.2} \mathrm{O}_{3-\delta}$ & Cathode & Marion Technologies & 10 & 0.85 \\
\hline $\mathrm{SSC}$ & $\mathrm{Sm}_{0.5} \mathrm{Sr}_{0.5} \mathrm{CoO}_{3-\delta}$ & Cathode & Fuel Cell Material & 1 & 9.7 \\
\hline $\mathrm{LSCF}$ & $\mathrm{La}_{0.6} \mathrm{Sr}_{0.4} \mathrm{Co}_{0.2} \mathrm{Fe}_{0.8} \mathrm{O}_{3-\delta}$ & Cathode & Fuel Cell Material & 3 & 3.9 \\
\hline $\mathrm{CGO}$ & $\mathrm{Ce}_{0.9} \mathrm{Gd}_{0.1} \mathrm{O}_{2-\delta}$ & Electrolyte & Fuel Cell Material & 5 & 7 \\
\hline $\mathrm{NiO}$ & $\mathrm{NiO}$ & Anode & Sigma-Aldrich & 5 & 2.4 \\
\hline
\end{tabular}

Table 2: Literature values of electrical conductivity of cathode materials

\begin{tabular}{|l|l|l|l|l|}
\hline & LSM & LSCF & BSCF & SSC \\
\hline$\sigma_{600^{\circ} \mathrm{C}}\left({\left.\mathrm{S} . \mathrm{cm}^{-1}\right)}^{-180[25]}\right.$ & $\sim 300-400[26]$ & $\sim 30[27]$ & $\sim 1000[24]$ \\
\hline
\end{tabular}

Table 3: Polarization resistance of each cathode under air at $650^{\circ} \mathrm{C}$

\begin{tabular}{|l|l|l|l|l|}
\hline & LSM/CGO & BSCF/CGO & SSC/CGO & LSCF/CGO \\
\hline $\operatorname{Rp}\left(\Omega \cdot \mathrm{cm}^{2}\right)$ & $\sim 55$ & $\sim 0.1$ & $\sim 0.05$ & $\sim 0.5$ \\
\hline
\end{tabular}

\section{Figure Captions}

Fig. 1 XRD patterns of LSM (a), LSCF (b), BSCF (c) and SSC (d) powders before and after stability test $\left(600^{\circ} \mathrm{C}, 5 \mathrm{~h}\right)$ under $\mathrm{CH}_{4} / \mathrm{O}_{2}=1.5$

Fig. 2 Electrical conductivity of cathode layers versus temperature under air (a) and $\mathrm{CH}_{4} / \mathrm{O}_{2}=1$ (b) atmosphere

Fig. 3 Catalytic activity of cathode powders toward $\mathrm{CO}_{2}$ production versus temperature, with a $\mathrm{CH}_{4} / \mathrm{O}_{2}$ ratio equal to

1 and 2

Fig. 4 Nyquist diagrams of LSCF/CGO cathode from $600^{\circ} \mathrm{C}$ to $700^{\circ} \mathrm{C}$

Fig. 5 Polarization resistance of LSM/CGO, BSCF/CGO, SSC/CGO and LSCF/CGO cathodes under air, $\mathrm{CH}_{4} / \mathrm{O}_{2}=1$ and $\mathrm{CH}_{4} / \mathrm{O}_{2}=2$ from $600^{\circ} \mathrm{C}$ to $700^{\circ} \mathrm{C}$

Fig. 6 Cross-section of cathode layers after polarization resistance measurement

Fig. 7 Cell voltage and power density curves of Ni-CGO/CGO/LSCF-CGO cell for $\mathrm{CH}_{4} / \mathrm{O}_{2}=2$ and $\mathrm{CH}_{4} / \mathrm{O}_{2}=0.67$

Fig. 8 Cell voltage and power density curves of Ni-CGO/CGO/LSCF-CGO cell for a temperature of $675^{\circ} \mathrm{C}$

Fig. 9 Maximum power density versus $\mathrm{CH}_{4} / \mathrm{O}_{2}$ ratio and temperature for each fuel cell with different cathode materials 


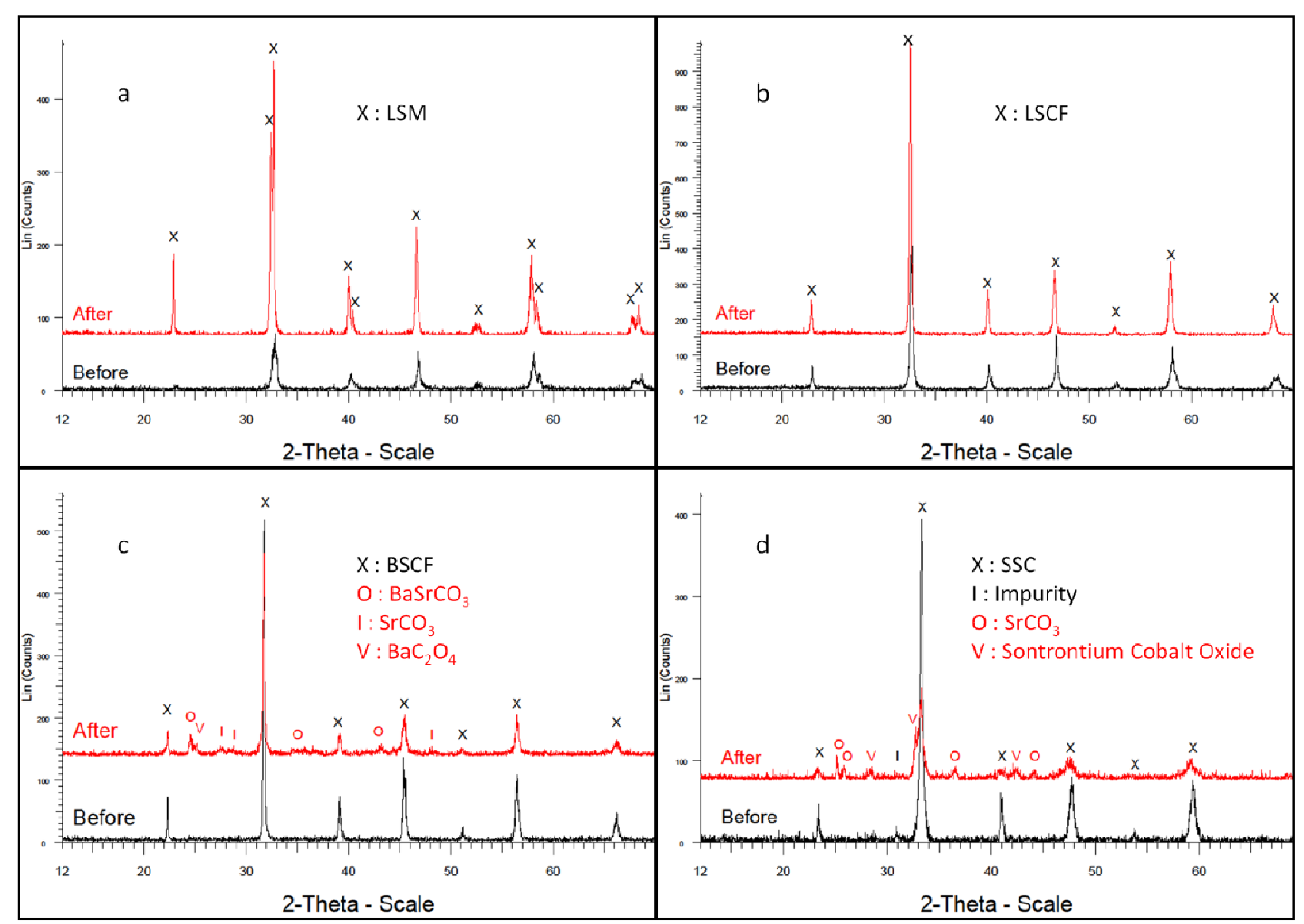

Figure 1: XRD pattern of LSM (a), LSCF (b), BSCF (c) and SSC (d) powders before and after stability test under $\mathrm{CH}_{4} / \mathrm{O}_{2}=1.5$

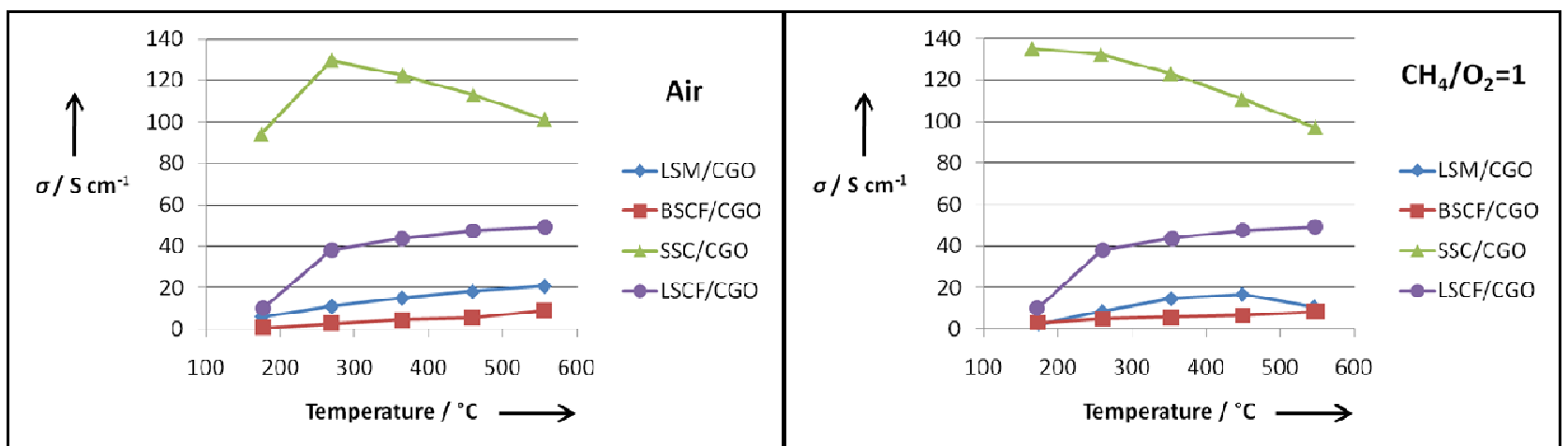

Figure 2: Electrical conductivity of cathode layers versus temperature under air (a) and $\mathrm{CH}_{4} / \mathrm{O}_{2}=1$ (b) atmosphere

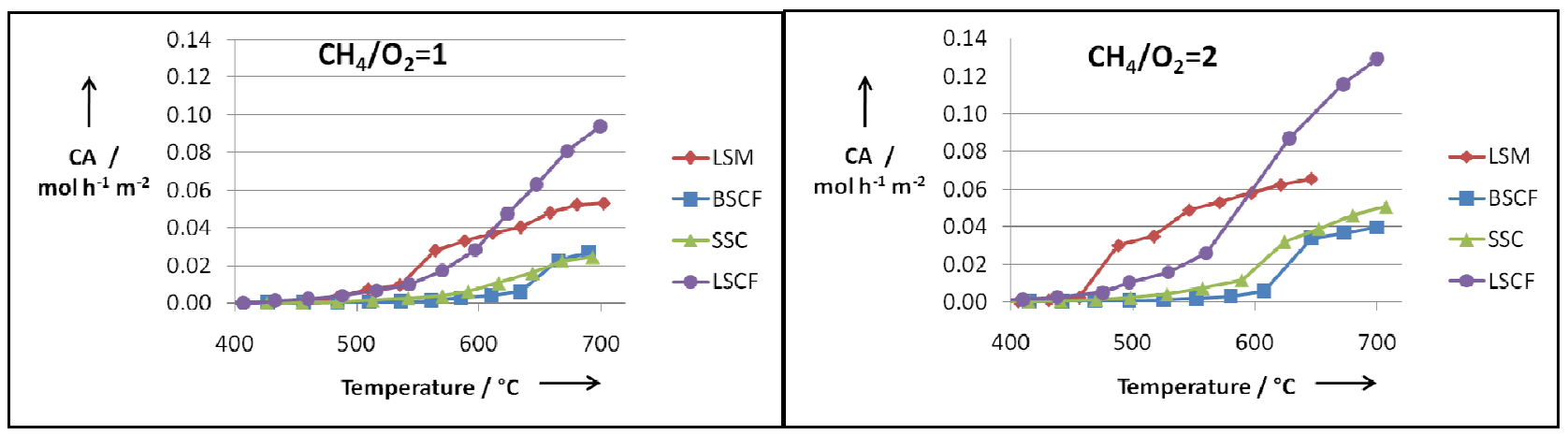

Figure 3: Catalytic activity of cathode powders toward $\mathrm{CO}_{2}$ production versus temperature, with a $\mathrm{CH}_{4} / \mathrm{O}_{2}$ ratio equal to 1 and 2 


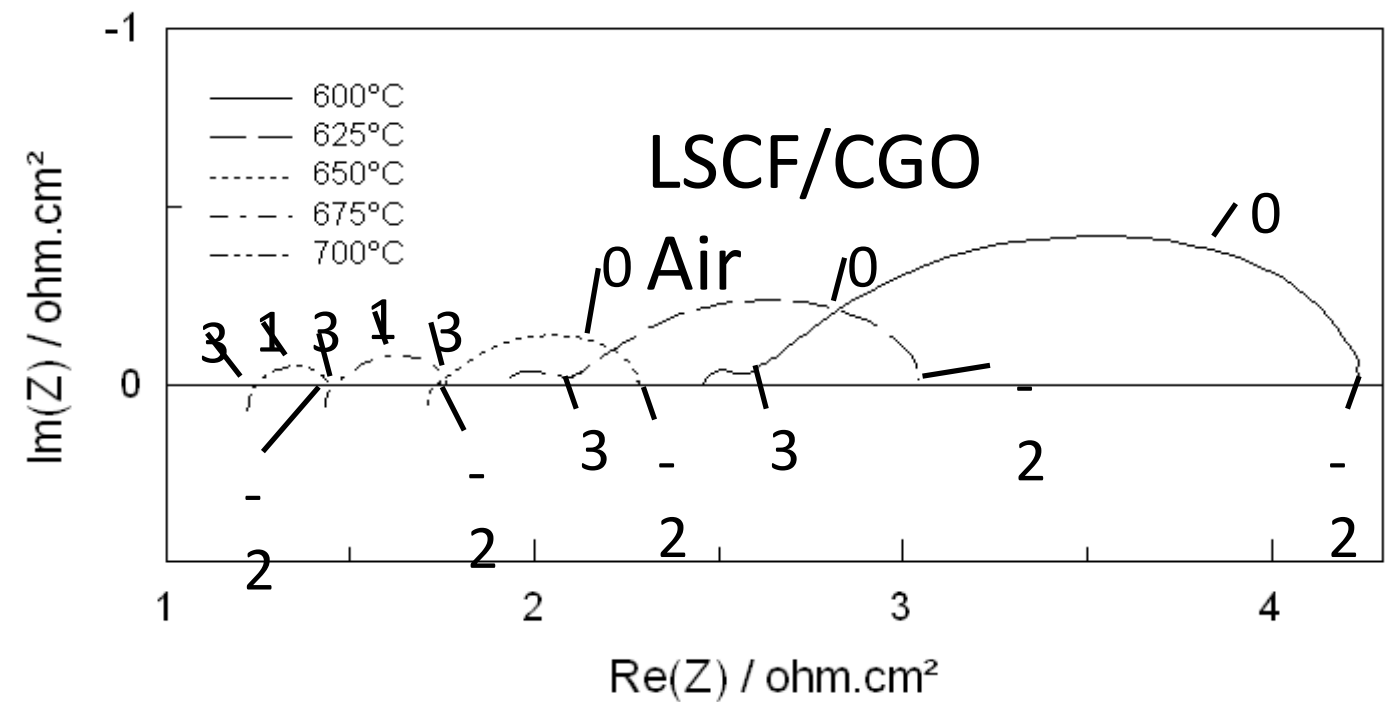

Figure 4: Nyquist diagrams of LSCF/CGO cathode from $600^{\circ} \mathrm{C}$ to $700^{\circ} \mathrm{C}$

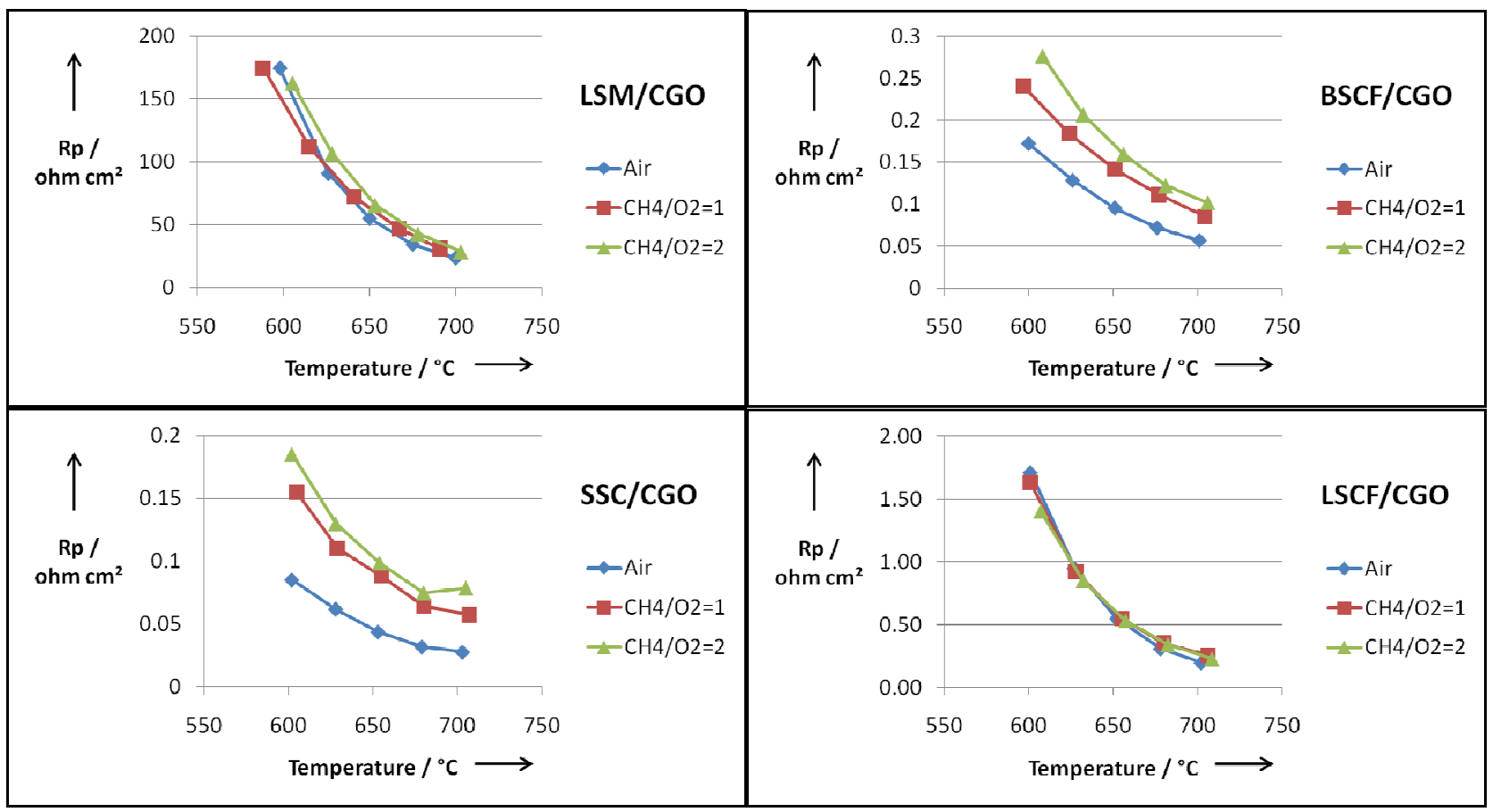

Figure 5: Polarization resistance of LSM/CGO, BSCF/CGO, SSC/CGO and LSCF/CGO cathodes under air, $\mathrm{CH}_{4} / \mathrm{O}_{2}=1$ and $\mathrm{CH}_{4} / \mathrm{O}_{2}=2$ from $600^{\circ} \mathrm{C}$ to $700^{\circ} \mathrm{C}$ 

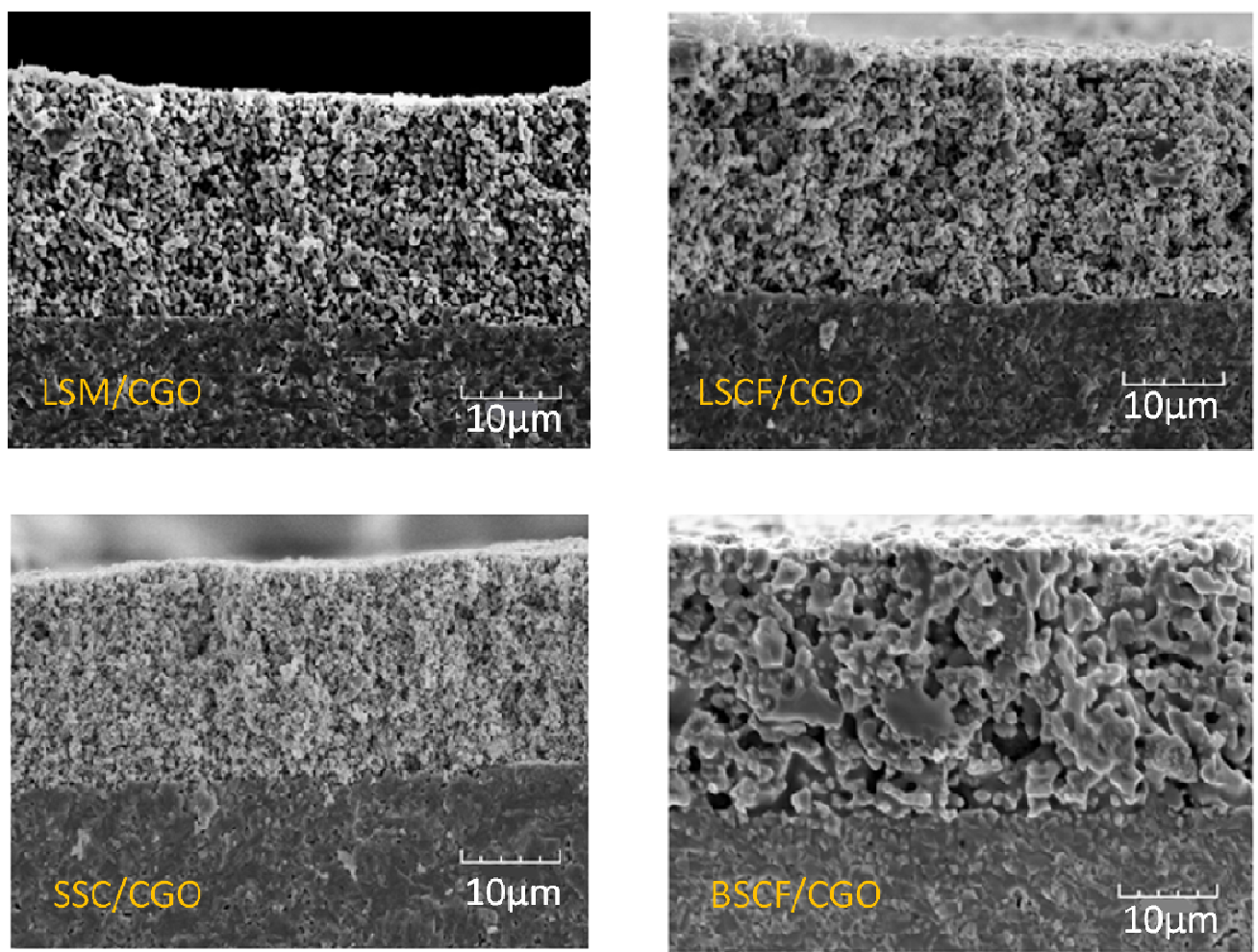

Fig. 6 Cross-section of cathode layers after polarization resistance measurement

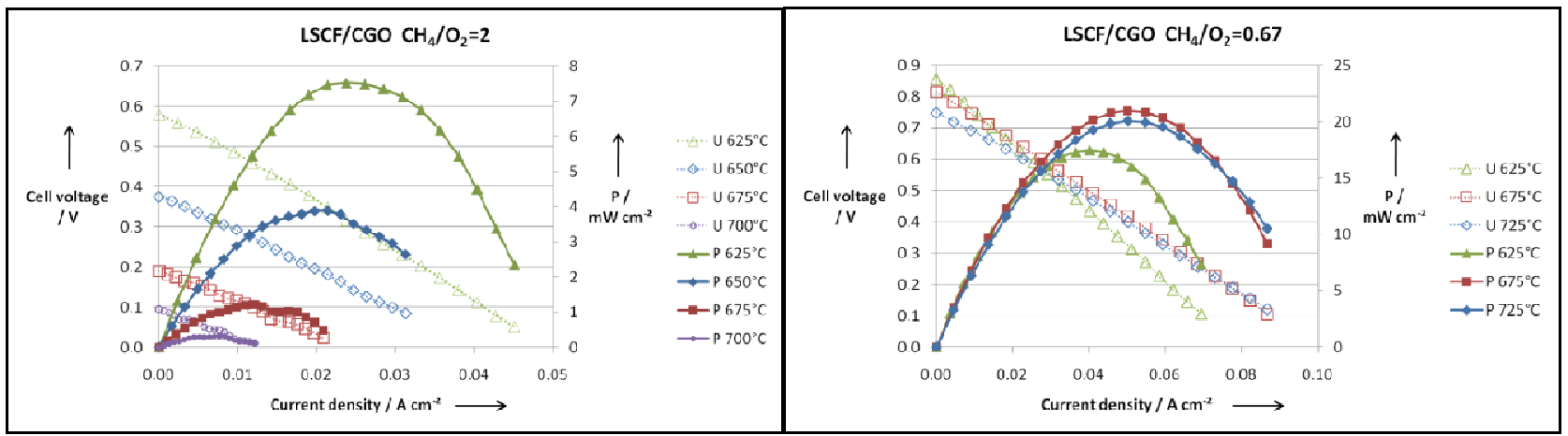

Figure 7: Cell voltage and power density curves of Ni-CGO/CGO/LSCF-CGO cell for $\mathrm{CH}_{4} / \mathrm{O}_{2}=2$ and $\mathrm{CH}_{4} / \mathrm{O}_{2}=0.67$ 


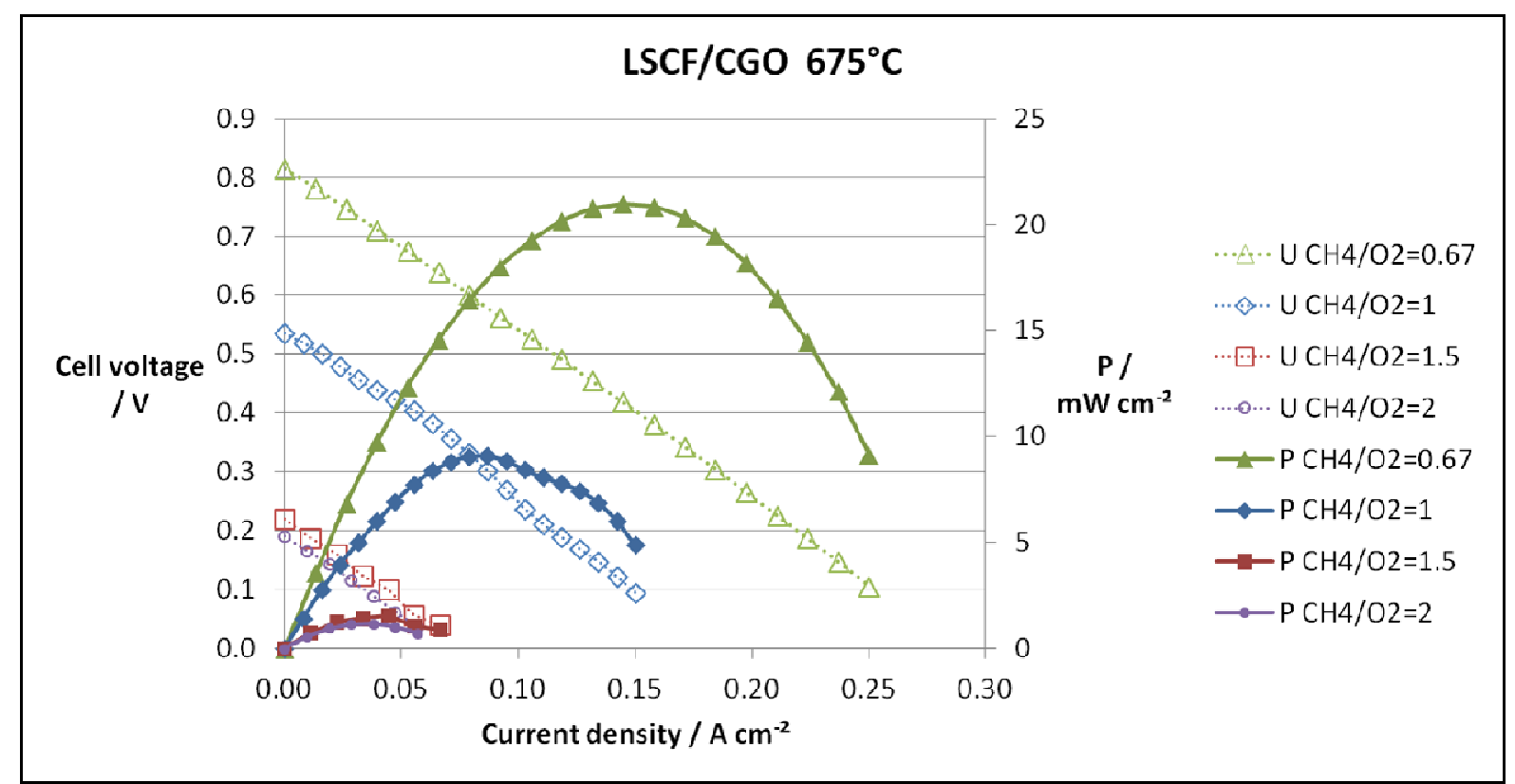

Fig. 8 Cell voltage and power density curves of Ni-CGO/CGO/LSCF-CGO cell for a temperature of $675^{\circ} \mathrm{C}$

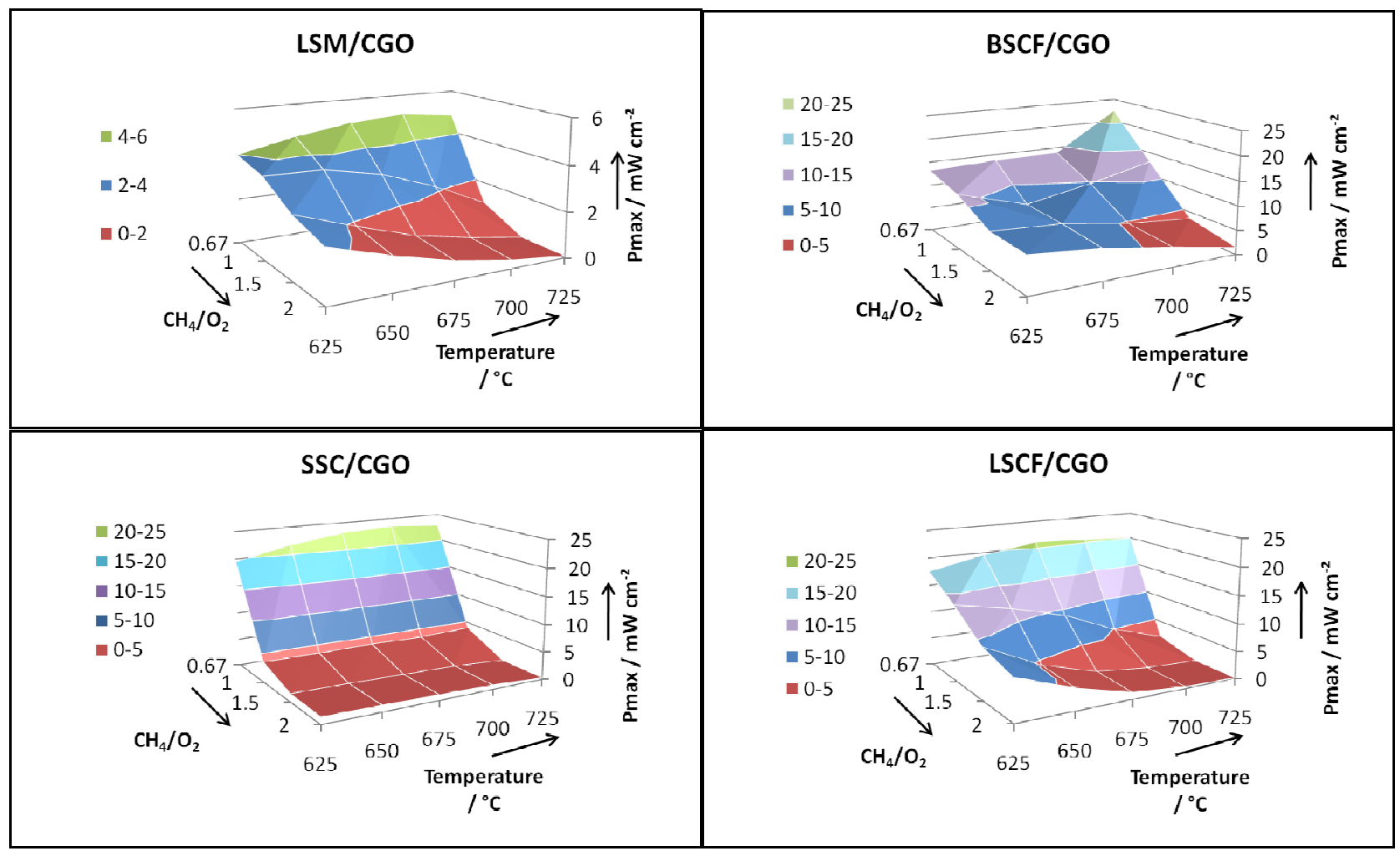

Figure 9: Maximum power density versus $\mathrm{CH}_{4} / \mathrm{O}_{2}$ ratio and temperature for each fuel cell with different cathode materials. 